УДК 336.2

DOI https://doi.org/10.17308/vsu.proc.law.2020.3/2987

\title{
АВТОМАТИЧЕСКИЙ ОБМЕН НАЛОГОВОЙ ИНФОРМАЦИЕЙ КАК СПОСОБ МЕЖДУНАРОДНОГО НАЛОГОВОГО КОНТРОЛЯ
}

\author{
О. А. Зыкова \\ Новосибирский национальный исследовательский \\ государственньй университет \\ Поступила в редакцию 10 февраля 2020 г.
}

\begin{abstract}
Аннотация: расслотрень основные принципь фбункиионирования взаилного обмена налоговой инбормацией, озвучен перечень лии, которые несут облзанность по предоставлению данной инфборлаиии, указан ее объел, который условно можно разделить на две категории в зависилости от отнесения реального владельиа банковского счета к числу ббизических или юридических лиц. Отдельное внилание уделено нарастающей проблеле, связанной с наличием противоречия приниипа неразглашения персональных данных и наличиел банковской, колмерческой тайны с приниипол открытости банковских сведений, на которол строится автолатический облен фбинансовой инборлацией. По результатам проведенного анализа авторол сделан вывод, что международно-правовые акты, реглалентирующие порядок автолатического облена инбормации, привели к усложнению деятельности предпринилательского сектора, а также позволили сделать процедуру передачи инфборлации о счетах более прозрачной, сокращая возложности бизнеса уклониться от налогов путели легализаиии незаконных доходов.

Ключевые слова: налогоплательщики, автолатический обмен налоговой инфборлацией, офббборные зоны, бенефбициары, единый стандарт по ведению отчетности.
\end{abstract}

\begin{abstract}
: in this article the basic principles of mutual information exchange functioning are considered, the list of persons who are obliged to provide tax information is sounded, its volume which conditionally can be divided into two categories depending on reference of the real owner of the Bank account to number of physical or legal persons is specified. Special attention is paid to the growing problem associated with the contradiction of the principle of non-disclosure of personal data and the presence of banking, commercial secrets with the principle of openness of banking information, which is based on the automatic exchange of financial information. According to the results of the analysis, the author concludes that the international legal acts regulating the automatic exchange of information have led to the complication of the business sector, as well as allowed to make the procedure for the transfer of information about accounts more transparent, reducing the ability of business to evade taxes by legalizing illegal income. Key words: taxpayers, automatic exchange of tax information, offshore zones, beneficiaries, unified reporting standard.
\end{abstract}

В настоящее время в России уделено особое внимание проблеме, связанной с наличием значительного числа экономических преступлений, а именно с легализацией доходов, полученных преступным путем. Данная проблема привела к острой необходимости и дальнейшим активным дей-

(C) Зыкова О. А., 2020 


\section{Вестник ВГУ. Серия: Право}

ствиям государства, направленным на переход к международным стандартам, регулирующим данный вопрос, и дальнейшему усовершенствованию законодательства в рассматриваемой сфрере ${ }^{1}$.

Цель статьи - рассмотрение не только теоретической основы автоматического обмена налоговой информацией, но и основной проблематики, связанной с защитой персональных данных и прав на личную жизнь, которая сформировалась в результате противоречия системы передачи налоговой информации с принципом конфиденциальности личных сведений и банковской тайны.

Затрагивая теоретический фундамент автоматического обмена информацией, изначально стоит упомянуть, что до 2016 г. основным ключевым моментом по борьбе с легализацией незаконно полученного дохода был Федеральный закон от 7 августа 2001 г. № 115-ФЗ «О противодействии легализации (отмыванию) доходов, полученных преступным путем, и фонансированию терроризма» (далее - ФЗ от 07.08.2001 №115$\Phi 3)^{2}$. Согласно данному нормативно-правовому акту все без исключения финансовые организации, которыми чаще всего выступали банки, должны были собственными силами осуществлять контроль за финансовыми операциями своих клиентов - владельцев банковских счетов. Данный контроль осуществляется согласно законодательству путем назначения ответственных лиц, которые в свою очередь принимают меры по противодействию отмыванию денег ${ }^{3}$. Основная проблематика в данном случае выражается в законодательном пробеле. Вышеуказанный закон не содержит в себе определенные конкретные критерии, по которым банк мог судить о законности или сомнительности отдельной финансовой операции. Поскольку всевозможные различные обстоятельства могут оцениваться с многообразных сторон по-разному, и ответственное по контролю лицо, m исходя из личных побуждений, может приостановить функционирова-

이 ние надежного банковского счета или же, наоборот, не уделить должного внимания сомнительной операции, стоит говорить о некорректности законодательства 4 .

Как отмечалось ранее, нарастающая проблема, приводящая к снижению экономического состояния России, вызвала необходимость у госу-

218 дарства принимать конкретные меры по ее устранению путем перехода национального законодательства к международным стандартам. Именно поэтому 12 мая 2016 г. в рамках Форума Организации экономическо-

${ }^{1}$ См.: Слепов В. А., Чекмарев В. Е. Сущность теневых финансовых потоков и факторы их формирования в современной экономике // Деньги и кредит. 2016. № 2. C. 50.

${ }^{2}$ Собр. законодательства Рос. Федерации. 2001. № 33 (ч. 1). Ст. 3418.

${ }^{3}$ См.: Волков И. И. Бюджетное маневрирование как инструмент бюджетной политики России // Финансы и кредит. 2016. № 21 (693). С. 54.

${ }^{4}$ См.: Батистова О. И. Сущность, особенности и перспективы развития офшорных зон в мировой экономике // Экономика и предпринимательство. 2017. № 1. C. 1150. 


\section{Финансовое право. Налоговое право}

го сотрудничества и развития (далее - ОЭСР), посвященного вопросам налогового администрирования, Федеральная налоговая служба России подписала Многостороннее соглашение компетентных органов об автоматическом обмене финансовой информацией от 29 октября 2014 г. ${ }^{5}$ (далее - MCAA). Реализация данного так называемого «проекта» впервые прошла в России в октябре 2018 г. ${ }^{6}$ Основная предпосылка участия в международном автоматическом обмене информацией была сформирована 30 ноября 2016 г. в опубликованном плане намерений и действий в налоговой сфере, предпринимаемых государством, разрабатываемом Минфином России, нашедшем свое отражение в «Основных направлениях налоговой политики РФ на 2016 год и на плановый период 2017 и 2018 годов» ${ }^{7}$.

Изначально необходимо выделить законодательные основы для обмена информацией на текущий момент. Во-первых, фрундаментом выступает Многостороннее соглашение компетентных органов об автоматическом обмене финансовой информацией от 29 октября 2014 г., основанное на ст. 6 Международной конвенции о взаимной административной помощи по налоговым делам 1988 г. (в ред. Протокола 2010 г.) ${ }^{8}$; во-вторых, немаловажным правовым актом в данном вопросе является Директива Европейского союза 2014/107 от 9 декабря 2014 г. (для обмена информацией между государствами - членами Европейского союза; Единого стандарта отчетности по автоматическому обмену информацией о фринансовых счетах (Common Reporting Standard, CRS) ${ }^{9}$, применяемому на международном уровне ${ }^{10}$.

В настоящее время согласно официальным источникам ОЭСР из России налоговая информация будет в автоматическом режиме отправляться в 61 страну, но более важная информация заключается в том, что Россия в свою очередь также в автоматическом режиме будет получать сведения из 86 государств ${ }^{11}$. В рамках рассматриваемого автоматического обмена в компетентные органы, которыми чаще всего выступают налоговые органы, задействованной юрисдикции будет поступать от финан-

\footnotetext{
${ }^{5}$ URL: http://www.oecd.org/ (дата обращения: 10.11.2019).

${ }^{6}$ См.: Орленко Н. Л. Проблемы введения автоматического обмена налоговой информацией // Устойчивое развитие науки и образования. 2017. № 3. С. 55-56.

${ }^{7}$ URL: http: // www.consultant.ru

${ }^{8}$ URL: http://www.oecd.org/ (дата обращения: 10.11.2019).

${ }^{9}$ Единый стандарт отчетности по автоматическому обмену информацией о финансовых счетах (Common Reporting Standard, CRS). URL: https://www.revenue. ie/en/companies-and-charities/documents/aeoi/common-reporting-standard-crs.pdf (дата обращения: 10.11.2019).

${ }^{10}$ См.: Гринякин С. А. Влияние соглашения об автоматическом обмене финансовой информацией на российскую систему противодействия легализации доходов, полученных преступным путем // Финансы и учет : вопросы теории и практики. Вестник АГТУ. Сер.: Экономика. 2017. № 2. С. 85.

${ }^{11}$ Организация экономического сотрудничества и развития // Официальный сайт. URL: http://www.oecd.org/ (дата обращения: 10.11.2019).
} 


\section{Вестник ВГУ. Серия: Право}

совых национальных учреждений информация относительно наличия и состояния счетов физических и юридических лиц, являющихся резидентами стран - участников CRS/MCAA, которая в дальнейшем ежегодно будет передаваться уполномоченным органам этих стран. Взамен этого первые имеют право на получение аналогичных данных от последних относительно счетов физических и юридических лиц - резидентов уже своей страны. Стоит отметить, что обмен информацией будет осуществляться ежегодно на автоматической основе в унифицированном электронном формате ${ }^{12}$.

Если рассмотреть более детально субъектный состав правоотношенийфинансовые институты, которые должны будут участвовать в обмене, то стоит выделить ограниченный перечень лиц, освобожденных от сбора и передачи информации (в целях обмена такие организации не признаются финансовыми институтами). Такими являются: правительственные органы и их личные фонды, международные организации, центральные банки и некоторые пенсионные фонды, квалифицированные эмитенты кредитных карт, необлагаемые налогом формы осуществления коллективных инвестиций, трастовые фонды, финансовая информация по которым подается управляющим, иные фринансовые институты с низким риском злоупотребления, которые утверждаются полномочными органами страны-участницы ${ }^{13}$. Россия со своей стороны пока только пытается воспользоваться вышеуказанным "полномочием», что отражается в рассмотрении законопроекта № 231414-7 от 20 июля 2017 г. «О внесении изменений в Налоговый кодекс Российской Федерации (в связи с реализацией международного автоматического обмена информацией о финансовых счетах и документацией по международным группам компаний)», в котором указывается, что «Правительство Российской Федерации вправе установить перечень организаций финансового рынка и (или) видов договоров, предусматривающих оказание фринансовых услуг, в отношении которых не применяются положения настоящей главы в силу низкого риска совершения с использованием таких организаций действий (бездействия), направленных на уклонение от уплаты налогов (сборов)» ${ }^{14}$.

Любые фринансовые институты, не включенные в приведенный выше перечень и не исключенные уполномоченным органом государства из перечня обменивающихся финансовых институтов, признаются обменивающимися фринансовыми институтами (в целях обмена), соответственно несут обязанность по передаче информации в соответствующие контролирующие их органы.

${ }^{12}$ См.: Орлова E. Ю. Современные тенденции внедрения в России автоматического обмена налоговой информацией // Финансы и налоговая политика : материалы II Междунар. науч.-практ. конф. М., 2017. С. 124-125.

${ }^{13}$ См.: Левашенко А. Д., Коваль А. А. Как работает международный автоматический обмен налоговой информацией // Экономическое развитие России. 2018. № 25(3). C. 71-73.

${ }^{14}$ URL: http://www.consultant.ru 


\section{Финансовое право. Налоговое право}

Рассмотрев субъектный состав, необходимо остановиться на объеме передаваемой информации. Согласно п. 2 ст. 2 МСАА в список основной информации, которая подлежит автоматическому обмену, входят следующие данные:

1) персональные сведения о налогоплательщике: имя фризического лица либо наименование юридического лица; идентификационный номер налогоплательщика; дата и место рождения физического лица; адрес юридического лица; имя, идентификационный номер, дата и место рождения фризических лиц, которые осуществляют функцию контроля за юридическим лицом (контролирующие юридические лица (после проведения идентификации в рамках процедуры due diligence в качестве «контролирующих лиц» данного юридического лица);

2) номер банковского счета налогоплательщика (в случае его отсутствия аналогичные по функции данные);

3) реквизиты (наименование и идентификационный номер) обслуживающего налогоплательщика финансового учреждения (банка);

4) остаток денежных средств на счете, приходящихся на конец соответствующего календарного года или на момент закрытия счета (в случае закрытия счета в этом году);

5) прочая информация по банковским счетам налогоплательщика: по счетам депо (Custodial Account); размер общей суммы процентов, дивидендов или иных доходов, полученных в результате активов, находящихся на таких счетах за календарный год или иной отчетный период; размер общей поступившей на счет выручки, полученной от продажи или выкупа активов, в отношении которых банк выступал депозитарием, брокером, номинальным держателем или агентом держателя счета; по депозитным счетам (Depository Account) размер общей суммы процентов, поступивших на счет за календарный год или иной отчетный период; по иным типам счетов - общая сумма, поступившая на счет держателя за календарный год или иной отчетный период ${ }^{15}$.

Таким образом, стоит отметить максимальную прозрачность всех денежных потоков как между физическими, так и между юридическими лицами. Данная информация позволяет отслеживать общий финансовый размер процентов, дивидендов или иного дохода, который формируется в отношении активов, хранящихся на таком банковском счете. Безусловно, стоит судить о значимости и важности вышеперечисленной информации для контроля со стороны налоговых органов и иных федеральных органов исполнительной власти ${ }^{16}$.

${ }^{15}$ Многостороннее соглашение компетентных органов об автоматическом обмене фринансовой информацией от 29 октября 2014 г. URL: http://www.oecd.org/ (дата обращения: 10.11.2019).

${ }^{16}$ См.: Андрианова Н. Г. Международный обмен налоговой информацией как правовой механизм противодействию уклонению от уплаты налогов организациями, зарегистрированными в низконалоговых юрисдикциях // Фундаментальные и прикладные исследования в современном мире. 2017. № 17-3. С. 120-121. 


\section{Вестник ВГУ. Серия: Право}

Однако вышеуказанная прозрачность создает еще и ряд дискуссионных вопросов относительно соотношения передачи персональных данных в рамках автоматического обмена с политикой конфиденциальности, неразглашения персональных данных. Поскольку при передаче информации происходит раскрытие личных сведений относительно физического лица, который также может выступать и бенефициарным собственником организации, стоит выделить острую проблему противоречия норм CRS/ MCAA с нормами иного законодательства, регулирующего права человека, к которым стоит отнести Всеобщую декларацию прав человека от 10 декабря 1948 г. ${ }^{17}$, Конвенцию о защите прав и основных свобод человека от 4 ноября 1950 г. ${ }^{18}$, Международный пакт о гражданских и политических правах от 16 декабря 1966 г. ${ }^{19}$ Необходимо также не забывать о наличии банковской, коммерческой, торговой, промышленной и профессиональной тайны, которые аннулируются после передачи сведений из одного государства в другой. Безусловно, в данном случае вся информация не относится к публичной и общедоступной, т. е. существует ограниченный перечень лиц, которые имеют доступ к сведениям и которые в дальнейшем несут ответственность за разглашение информации или использовании ее в личных целях. В любом случае это обстоятельство вызвало шквал спорных рассуждений, недовольств со стороны налогоплательщиков, которые не желают жертвовать неприкосновенностью своих личных данных и которые стараются всячески избегать налоговых претензий в свой адрес ${ }^{20}$.

Можно констатировать, что до сих пор существуют открытые нерешенные важные вопросы относительно обмена налоговой информацией, которые связаны не с технической составляющей данной «программы», a с системой ее реализации. Основной вопрос, который формируется: действительно ли развитые государства будут предоставлять в полном объеме налоговую информацию? Без движения остается также вопрос о предотвращении ненадлежащего использования полученной налоговой информации с целью дальнейшего негативного воздействия на владельцев банковских счетов. В любом случае каждый бенефициарный собственник счета уже сегодня понимает, что современный мир активно продвигается к глобальной прозрачности в финансовых вопросах, при этом прежнее значение и потенциалы банковской тайны в рамках сохранения информации о клиенте и его финансовых движениях утратили былую силу. Сейчас вне зависимости от места нахождения финансового учреждения стандарт автоматического обмена позволяет обнаружить все заграничные активы налогоплательщика, которые и в дальнейшем

\footnotetext{
${ }^{17}$ Рос. газета. 1995. № 67.

${ }^{18}$ Собр. законодательства Рос. Федерации. 2001. № 2. Ст. 163.

${ }^{19}$ Ведомости Верховного Совета СССР. 1976. № 17. Ст. 291.

${ }^{20}$ См.: Бабенко А. Ю. Приватность и банковская тайна в контексте международного автоматического обмена налоговой информацией // Молодий вчений. 2015. № 12 (27). C. 64-65.
} 


\section{Финансовое право. Налоговое право}

подлежат репатриации и налогообложению согласно законодательству родного государства.

Новосибирский национальный исследовательский государственный универcumem

Зыкова О. А., соискатель ученой степени кандидата юридических наук

E-mail: bubenova90@mail.ru
Novosibirsk National Research State University

Zykova O. A., Applicant of the Degree of Candidate of Legal Sciences

E-mail: bubenova90@mail.ru 